\title{
The Role of Knowledge Sharing to Improve the Quality of Human Resources
}

\author{
Zaenudin Tachyan ${ }^{1}$, MLN. Rosmadi ${ }^{2}$, Sri Maria Ulfha ${ }^{3}$ \\ ${ }^{123}$ Institute of Economic Science Kridatama Bandung, Indonesia \\ Corresponden Author: maskartolucky@gmail.com
}

\begin{abstract}
This study aims to determine the role of knowledge sharing in order to improve the quality of human resources. The research method used is a qualitative method with a descriptive explorative approach. From the results of the research conducted, the results show that the quality of human resources can be increased not only through formal education but can also be done through knowledge sharing among fellow employees and also received support from management, especially related to motivation, appreciation, and career path. With the sharing of knowledge, it will increase innovation and creativity of employees so that production can be improved and have high competitiveness so that it affects consumers' interest in buying woven products produced by craftsmen in Majalaya, Bandung Regency.
\end{abstract}

Keyword : Human Resources; Sharing Knowledge; Work Motivation.

\section{Introduction}

Micro, Small and Medium Enterprises and the creative economy are the foundation for economic growth in Indonesia. This shows, that the creative industry has good prospects for development and competitiveness and competitive advantage if managed properly. The creative industry also contributes significantly to the economy of local communities and local governments and contributes to the creation of jobs. Therefore, the development of the quality of human resources must be the top priority that must be carried out by the management of the organization in order to survive and develop in accordance with the objectives of the organization [1]; [2]; [3]. In addition, knowledge management also needs to be improved in order to improve the quality of employee performance so that production competitiveness can be realized [4-7].

The limited quality of education possessed by employees must be addressed by management by sharing knowledge. This greatly helps the company to produce quality human resources that have competitiveness and improve the operational performance of the organization [8]; [9]. Sharing knowledge about the limitations of employees at the education level can be overcome and will increase innovation and work motivation of employees in improving the quality of production. By increasing yield and quality of production results will have an impact on organizational growth and improve employee welfare [10-14]. Once the importance of knowledge sharing for business organizations amid the limited level of education possessed by Indonesian human resources, the authors are interested in examining it further in relation to the extent of the role of knowledge sharing to improve the quality of Indonesian human resources in creativity and innovation to have high competitiveness.

\section{Review of Literature}

\subsection{Human Resources}

Human resources in a business organization are invaluable assets. The development of science must be the concern of management so that the ability and quality of its resources can be improved according to needs. This is done so that employees have adequate knowledge and competence as a competitive advantage for the continuity and progress of the company 
[15]; [16]. Given the importance of human resources for organizations, it can be concluded that employees or human resources are at the heart of the knowledge management philosophy [17]; [18].

The results of research conducted by Currie \& Kerrin [19], Collins \& Smith [20], Minbaeva (a) [21], Minbaeva (b) [22], DeLong \& Fahey [23], Nayir \& Uzuncarsili [24] can be concluded that human resources are the best resources owned by business organizations whose continuity must be fostered both through formal and informal education to achieve the expected goals.

\subsection{Sharing Knowledge}

The progress of business organizations depends on the available resources, especially the human resources they have. This is done so that the quality of production has a high competitiveness, especially after the entry into force of the ASEAN free market at the end of 2015. However, the obstacles faced by the Indonesian nation to improve the quality of human resources are at the level of education. junior high school level. Ipe [25] and Pervaiz et al. [26] states, that an organization will develop and success must equip its employees with knowledge. Such knowledge is intellectual capital that can be obtained either through formal education, non-formal education or providing mutual experience among its employees [27].

Therefore, giving mutual knowledge among fellow employees besides being able to improve the quality of employee work will also be able to increase employee confidence which in turn can increase the quantity and quality of production [28]; [29]. The results of the study conducted by Arthur \& Huntley [30], Cummings [31], Hansen [32], Magnus \& DeChurch [33] can be concluded that knowledge sharing has a positive impact on business organizations specifically related to finance, innovation and creativity production, and improve employee performance.

\subsection{Work motivation}

In business organizations, the skills and expertise of employees are highly demanded to support the tasks or jobs assigned to them. In addition, the company must also be able to increase employee motivation and conduct work evaluations in order to create optimal organizational performance [34]; [35]; [39]. By having a high work motivation, it is expected that employees can get rewards from companies that have an impact on improving welfare. This is in line with the opinion of Deci \& Ryan [40] which states that motivation is the power of supporting employees to carry out an activity or work effectively and focus to achieve the expected goals. From the results of research conducted by Bakar [36], Achmad [37], and Aima, Adam \& Ali [38] it can be concluded that increasing employee performance is influenced by several factors including competency, motivation, knowledge, and job satisfaction.

\section{Research Methods}

The research was conducted from July to December 2018 in the weaving industry that produces sarong fabric in Majalaya, Bandung Regency. The method used is a qualitative method with a descriptive explorative approach. The type of data collected is primary data obtained through in-depth interviews with information sources (informants). In conducting surveys, researchers use a personal approach (unstructured questionnaire) to obtain 
information related to the bag industry business. Data analysis techniques in this study used a descriptive qualitative interactive model in the form of data collection, data reduction, display data, and conclusions / interpretative verification.

\section{Results and Discussion}

Sentral tenun Majalaya Bandung Regency is one of the centers of the textile industry in West Java that produces batik, woven and songket fabrics which are in great demand by consumers both from domestic and abroad. Most of the Majalaya weaving industry centers still use Non-Machine Weaving Tools (ATBM), whose work still prioritizes human power as its main resource. The existence of a monetary crisis that hit almost all countries in the world had an impact on the reduction of Majalaya weaving craftsmen. If before the crisis in 1998 the number of craftsmen was 250 craftsmen, now in 2018 the number of craftsmen is only 59 craftsmen. This certainly has an impact on the increase in unemployment coupled with a low level of education which makes it difficult for them to move to work.

The production results are produced by the Majalaya weaving small-scale industry (IKM) which received support from the government of West Java Province through the Department of Industry and Trade even though they still use ATBM but the quality cannot be used again. This can be seen in the following picture:
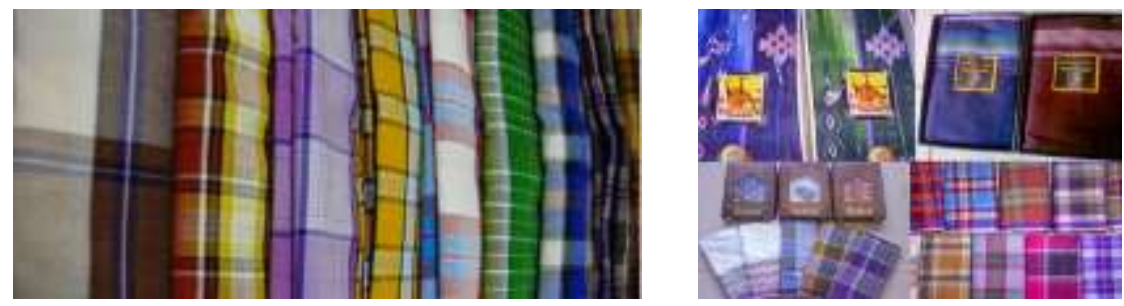

Figure 1. ATBM Majalaya Weaving Results [41]

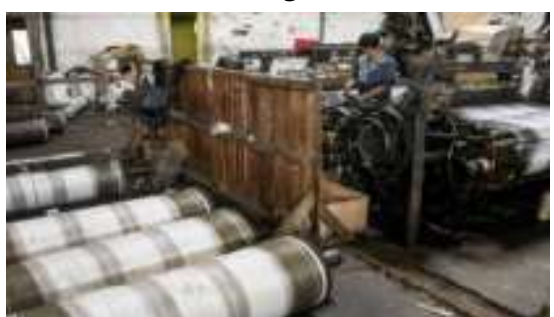

Picture. $1[42\rceil$

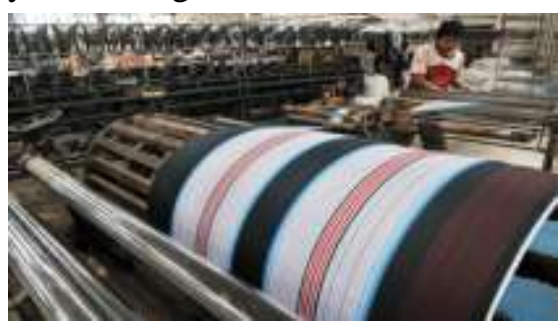

Picture. $2[43]$

Figure 2. ATBM engine

From figure 1, it can be explained that the quality of Majalaya's weaving in the form of sarong and songket is of reliable quality and can compete with similar goods from other countries. While in figure 2, although the looms used by craftsmen mostly still use NonMachine Weaving Tools (ATBM), thanks to the skills possessed by workers, they can produce quality woven fabrics.

This is certainly in accordance with the opinion expressed by Bakar [28] and Ahmad [29] that skills and knowledge can be obtained not only through formal channels but through exchanging experiences among employees is the right way to improve the quality of human resources amid high costs education. This opinion was confirmed by Holste \& Fields [34], Hassan et al. [35], and Kuvaas et al. [39] that the support provided by company management 
in the form of work motivation can improve organizational performance both work productivity and production quality.

The two opinions above are supported by the results of research conducted by Arthur \& Huntley [30], Cummings [31], Hansen [32], Magnus \& DeChurch [33] which states that improving the quality of human resources (employees) in addition to formal education can also be obtained from knowledge sharing among employees in an effort to improve innovation and creativity. Besides the results of research conducted by Bakar [36], Achmad [37], and Aima, Adam \& Ali [38] which states that the quality of human resources to be able to increase and develop especially for the advancement of business organizations is also influenced by encouragement and motivation from management mainly deals with awards and career paths.

Thus we can understand that to improve the quality of human resources in business organizations is not only obtained through formal and structured education, but can be done through various ways such as sharing knowledge between fellow employees and support from management to employees for the development and progress of the company.

\section{Conclusion}

From the description above, it can be seen that the role of knowledge sharing in business organizations plays a major role in improving the quality of human resources. The limitations of formal education possessed by employees in order to have competitiveness with regard to the quality of production can be overcome by the support of management and cooperation among employees to improve the welfare and development of business organizations.

\section{References}

[1] Hilmi Aulawi, Rajesri Govindaraju, Kadarsah Suryadi, and Iman Sudirman, "Hubungan Knowledge Sharing Behaviour dan Individual Innovation Capability," Jurnal Teknik Industri, vol. 11, no. 2, pp. 174-187, 2009.

[2] Chung-Jen Chen and Jing-Wen Huang, "Strategic Human Resource Practices and Innovation Perfor $\neg$ mance: The Mediating Role of Knowledge Management Capacity," Journal of Business Research, vol. 62, no. 1, pp. 104-114, 2011.

[3] Daniel Jimenez and Raquel Sanz Valle, "Studying the effect of HRM practices on the knowledge management process," Personnel Review, vol. 42, no. 1, pp. 28-49, 2012.

[4] Graeme Currie and Maire Kerrin, "Human resource management and knowledge management: enhancing knowledge sharing in a pharmaceutical company," The International Journal of Human Resource Management, vol. 14, no. 6, pp. 1027-1045, 2003.

[5] T.T. Selvarajan and Peggy A. Cloninger, "Can performance appraisals motivate employees to improve performance? A Mexican study," The International Journal of Human Resource Management, vol. 23, no. 15, pp. 3063-3084, 2012.

[6] Donald Hislop, "Linking human resource management and knowledge management via commitment: A review and research agenda," Employee Relations, vol. 25, no. 2, pp. 182-202, 2003.

[7] Victor Oltra, "Knowledge management effectiveness factors: the role of HRM," Journal of Knowledge Management, vol. 9, no. 4, pp. 70-86, 2005.

[8] Maxine Robertson and Geraldine O'Malley Hammersley, "Knowledge management practices 
within a knowledge-intensive firm: the significance of the people management dimension," Journal of European Industrial Training, vol. 24, no. 2/3/4, pp. 241-253, 2000.

[9] Meng-Hsiang Hsu, Teresa L. Ju, Chia-Hui Yen, and Chun-Ming Chang, "Knowledge sharing behavior in virtual communities: The relationship between trust, self-efficacy, and outcome expectations," International Journal of Human Computer Studies, vol. 65, no. 2, pp. 153-169, 2007.

[10] Graeme Currie and Maire Kerrin, "Human resource management and knowledge management: enhancing knowledge sharing in a pharmaceutical company," International Journal of Human Resource Management, vol. 14, no. 6, pp. 1027-1045, 2003.

[11] Christopher J. Collins and Ken G. Smith, "Knowledge exchange and combination: the role of human resource practices in the performance of high-technology firms," Academy of Management Journal, vol. 49, no. 3, pp. 544-560, 2006.

[12] Dana B. Minbaeva (a), "HRM practices and mnc knowledge transfer," Personnel Review, vol. 34, no. 1, pp. 125-144, 2005.

[13] Dana B. Minbaeva (b), "HRM practices affecting extrinsic and intrinsic motivation of knowledge receivers and their effect on intra-MNC knowledge transfer," International Business Review, vol. 17, no. 6, pp. 703-713, 2008.

[14] David W. DeLong and Liam Fahey, "Diagnosing cultural barriers to knowledge management," Academy of Management Executive, vol. 14, no. 4, pp. 113-127, 2000.

[15] Dilek Zamantili Nayir and Ulku Uzuncarsili, "A cultural perspective on knowledge management: the success story of Sarkuysan company," Journal of Knowledge Management, vol. 12, no. 2, pp. 141-155, 2008.

[16] Minu Ipe, "Knowledge sharing in organizations: A conceptual framework," Human resource Development Review, vol. 2, no. 4, pp. 337-359, 2003.

[17] Uzma Pervaiz et al., "Human resource practices and knowledge sharing: The moderating role of trust," International Journal of Organizational Leadership, vol. 5, pp. 15-23, 2016.

[18] Damian Grimshaw and Marcela Miozzo, "New human resource management practices in knowledge-intensive business service firms: The case of outsourcing with staff transfer," Human Relations, vol. 62, no. 10, pp. 1521-1550, 2009.

[19] Alvaro Lopez Cabrales, Ana Perez Luno, and Ramon Valle, "Knowledge as a mediator between HRM practices and innovative activity," Human Resource Management, vol. 48, no. 4, pp. 485503, 2009.

[20] Nien-Chi Liu and Min-Shi Liu, "Human resource practices and individual knowledge-sharing behavior: An empirical study for Taiwanese R \& D professionals," International Journal of Human Resource Management, vol. 22, no. 4, pp. 981-997, 2011.

[21] Jeffrey B. Arthur and Christopher L. Huntley, "Ramping up the organizational learning curve: Assessing the impact of deliberate learning on organizational performance under gainsharing," Academy of Management Journal, vol. 48, no. 6, pp. 1159-1170, 2005.

[22] Jonathon N. Cummings, "Work groups, structural diversity, and knowledge sharing in a global organization," Management Science, vol. 50, no. 3, pp. 362-364, 2004.

[23] Morten T. Hansen, "Knowledge network: Explaining effective knowledge sharing in multiunit companies," Organization Science, vol. 13, no. 3, pp. 232-248, 2002.

[24] Jessica R. Mesmer-Magnus and Leslie A. DeChurch, "Information sharing and team performance: A meta-analysis," Journal of Applied Psychology, vol. 94, pp. 535-546, 2009.

[25] Raymond A. Noe, John R. Hollenbeck, Barry Gerhant, and Patrick M. Wright, Human resource management: Gaining a competitive advantage, 8th ed.: McGraw-Hill Education, 2018.

[26] Ayman A.S. Almusaddar, Sara Ravan Ramzan, and Valliappan Raju, "The Influence of 
Knowledge, Satisfaction, and Motivation on Employee Performance Through Competence," International Journal of Business and General Management (IJBGM), vol. 7, no. 5, pp. 21-40, 2018.

[27] Ramli Bakar, "The effect of learning motivation on student's productive competencies in vocational high school, West Sumatra," International Journal of Asian Social Science, vol. 4, no. 6, pp. 722-732, 2014.

[28] Suryana H. Achmad, "The Effect of Competency, Motivation, and organizational Culture on the Employee Performance at the Jayakarta Hotel, Bandung, Indonesia," Journal of Business on Hospitality and Tourism, vol. 2, no. 1, pp. 136-146, 2016.

[29] Havidz Aima, Rizki Adam, and Hapzi Ali, "Model of Employee Performance: Competence Analysis and Motivation (Case Study at PT. Bank Bukopin, Tbk Center)," Quest JournalsJournal of Research in Business and Management, vol. 4, no. 11, pp. 49-59, 2017.

[30] Carmen Camelo, Joaquin Garcia Cruz, Elena Sousa Ginel, and Ramon Valle, "The Influence of Human Resource Management on Knowl 7 edge Sharing and Innovation in Spain: The Mediating Role of Affective Commitment," International Journal of Human Resources Management, vol. 22, no. 7, pp. 1442-1463, 2011.

[31] Whisnu Elianto and Nuri Ariani Wulansari, "Building Knowledge Sharing Intention with Interper $\neg$ sonal Trust as a Mediating Variable," jurnal Manajemen Teknologi, vol. 15, no. 1, pp. 67-76, 2016.

[32] Hsiu-Fen Lin, "Knowledge sharing and firm innovation capability: an empirical study," International Journal of Manpower, vol. 28, no. 2/3, pp. 315-332, 2007.

[33] Bard Kuvaas, Robert Buch, and Anders Dysvik, "Perceived Training Intensity and Knowledge Sharing: Sharing for Intrinsic and Prosocial Reasons," Human Resource Management, vol. 51, no. 2, pp. 167-187, 2012.

[34] J. Scott Holste and Dail Fields, "Trust and tacit knowledge sharing and use," Journal of Knowledge Management, vol. 14, no. 1, pp. 128-140, 2010.

[35] Masoodul Hassan, Nilufer Vatansever, Fatih Semercioz, and Ibrahim Aksel, "Interpersonal trust and its role in organizations," International Business Research, vol. 5, no. 8, pp. 33-39, 2012.

[36] Birgit Renzl, "Trust in management and knowledge sharing: The mediating effects of fear and knowledge documentation," Journal of Omega, vol. 36, no. 2, pp. 206-220, 2008.

[37] D. Sandy Staples and Jane Webster, "Exploring the effects of trust, task interdependence and virtualness on knowledge sharing in teams," Information Systems Journal, vol. 18, no. 6, pp. 617-640, 2008.

[38] Hazel Hall and Melanie Goody, "KM, culture, and compromise: Interventions to promote knowledge sharing supported by technology in corporate environments," Journal of Information Science, vol. 33, no. 2, pp. 181-188, 2007.

[39] Baar Kuvaas, Robert Buch, Marylene Gagne, Anders Dysvik, and Jaquest Forest, "Do you get what you pay for? Sales incentives and implications for motivation and changes in turnover intention and work effort," Motivation \& Emotion, vol. 40, no. 5, pp. 667-680, 2016.

[40] Edward L. Deci and Richard M. Ryan, "The" what" and" why" of goal pursuits: Human needs and the selfdetermination of behavior," Psychological Inquiry, vol. 11, no. 4, pp. 227-268, 2000.

[41] Ade Sulchi. (2016, Mei) Tenun Majalaya Bandung Jawa Barat. [Online]. https://gpswisataindonesia.wordpress.com/2015/03/03/tenun-majalaya-bandung-jawa-barat/

[42] Muhammad Fauzi Ridwan and Friska Yolanda. (2018, September) Pengusaha Sarung di Majalaya Kurang Produksi. [Online]. https://www.republika.co.id/berita/nasional/daerah/18/09/11/pewhje370-pengusaha-sarung-dimajalaya-kurangi-produksi 
Budapest International Research and Critics Institute-Journal (BIRCI-Journal) Volume 2, No 1, February 2019, Page: 186-192 e-ISSN: 2615-3076(Online), p-ISSN: 2615-1715(Print)

www.bircu-journal.com/index.php/birci emails: birci.journal@gmail.com birci.journal.org@gmail.com
[43] Zenny.
(2015,
May)
Pabrik
Sarung
Majalaya.
[Online]. https://pabriksarungtenunmajalaya.wordpress.com/ 